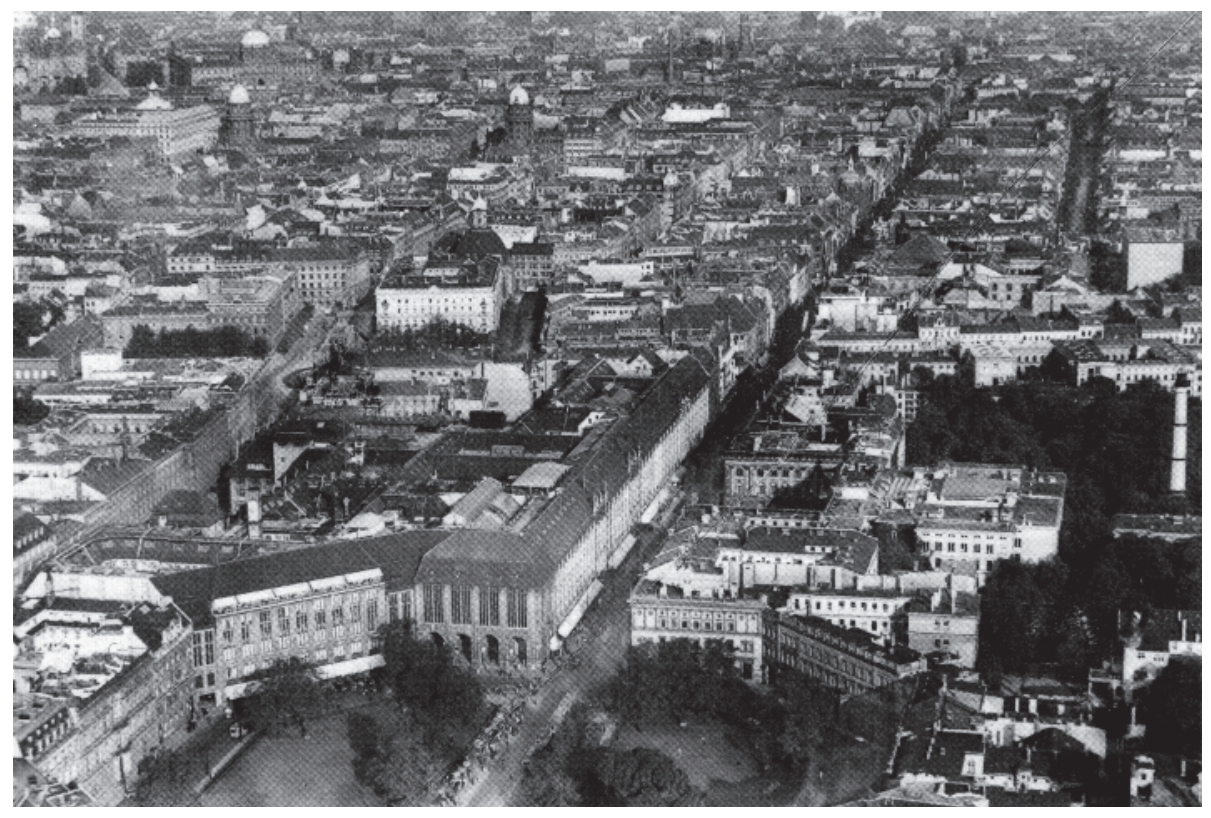

Aerial view of Wertheim

Warenhaus, Leipziger Platz and

Leipziger Straße, Berlin, ca. 1930.

From Karl Scheffler, Der Architekt

und andere Essays (1993). 


\section{Metropolitan Architecture: Karl Scheffler and Alfred Messel's Search for a New Urbanity}

\section{ALEXANDER EISENSCHMIDT}

Just over a century ago, the art and architectural critic Karl Scheffler noted, "it is no accident that at the moment when the inherent organization of the metropolis is propelled by the pressures of economy, a new form of metropolitan architecture emerges for which the department store has become the symbol."1 This definition of a modern architecture, intimately related to the modern city and its spatial and commercial pressures, was for Scheffler most vividly expressed in the Wertheim department store in Berlin, designed by Alfred Messel from 1896 to 1904.

Messel's design was of repeated interest to Scheffler, who addressed the building in numerous articles and books such as Moderne Baukunst (Modern building art, 1907), Berlin-Ein Stadtschicksal (Berlin-Destiny of a city, 1910), and, most explicitly, in Die Architektur der Großstadt (Metropolitan architecture, 1913). ${ }^{2}$ The Wertheim store, one of the largest in Europe and a place for the transient, theatrical, and fantastic experience of commerce, was, according to Scheffler, a key to understanding a new architectural paradigm. In Wertheim Scheffler detected not only a new building type for a society of consumers but also a new relationship of this typology to the city. To him, the forces of the metropolis had brought about and shaped new spatial and organizational conditions, which architectural discourses at the turn of the century had failed to recognize. The new building types of the modern city, and the department store in particular, announced a new architecture of the metropolis, which Scheffler saw emerging only from within the current urban condition and poignantly called Großstadtarchitektur (metropolitan architecture). ${ }^{3}$ While acknowledging the evolution of the store as directly related to the commercial and industrially driven modern city, Scheffler identified architectural innovations in the spaces that, at best, were viewed as mere residues of the modern city and, even more often, considered to be harmful to architecture. Consequently, the later building phases, when the Wertheim store grew more massive and uniform, prompted Scheffler to develop a notion of the building façade and urban block as a pro- 
ductive extrapolation of the metropolis. ${ }^{4}$ These insights were not only taken up by critics and architects in his immediate vicinity but resonated in the ideas of an urban architecture that would captivate later generations: from Ludwig Hilberseimer's Großstadtarchitektur to the Office of Metropolitan Architecture. ${ }^{5}$

This intersection between the design of Messel and the theories of Scheffler has so far not been properly understood for its historical importance or its relevance in the trajectory toward an architectural urbanism of the metropolis. As such, this article is not merely a story of a theorist and a practitioner, which together help us to better understand how certain spatial experiences have come to be associated with the rise of urban commerce. More important, it proposes an alternative trajectory within architectural modernism, one that is not predicated on the narratives of tectonic functionalism or technological inventions but on architecture's intimate relationship with the metropolis. In Messel and Scheffler's rejection of an outright resistance or unconditional embrace of metropolitan forces, one can detect an openness that counters both the rigid Städtebau (city planning) mentalities at the time as well as the more definitive modernisms of the $1920 \mathrm{~s}$ and 1930s. ${ }^{6}$ But rather than considering their work solely as transitional within modernity, this article proposes that their engagement with the metropolis exposes a theoretical opportunism that offers an alternative to the "either/or" categorical discourse of modernity as well as a tactical device instructive for architects to come. ${ }^{7}$ Or, to use Marshall Berman's provocation, “To appropriate the modernities of yesterday can be at once a critique of the modernities of today and an act of faith in the modernities . . . of tomorrow and the day after tomorrow."8

\section{| III}

During the first two decades of the twentieth century, Scheffler's writings on art and architecture became known for their outspokenness and often controversial positioning of modernity. ${ }^{9} \mathrm{He}$ belonged to a new generation of critics in Germany who questioned the academic traditions of the nineteenth century and understood themselves as part of a new metropolitan modernity. ${ }^{10}$ Enormously productive during these years, Scheffler not only headed the influential journal Kunst und Künstler but wrote for numerous other magazines such as Die Zukunft and extended his readership through popular venues such as the Vossische Zeitung, where he was in charge of the arts column. In addition, he published multiple books on subjects that spanned art, politics, and literary and travel reports. His writings on art showed him to be deeply committed to German impressionism. ${ }^{11}$ The maturing of German impressionism in parallel to the reassessment 
of nineteenth-century aesthetic theory prompted an altered perception of the modern city. ${ }^{12}$ For some figures in Scheffler's circle, such as the architect August Endell, a visual reworking of the city came with observations of the urban environment through the heightened impressionist colorations of atmospheric effects, as Endell explored in his publication Die Schönheit der Großen Stadt (The beauty of the metropolis) in $1908 .{ }^{13}$ For Scheffler, the potential of impressionism was less its analytic capacities than its ability to move beyond preconceptions of the metropolis. ${ }^{14}$

While his unabashed allegiance to impressionism resulted in often hostile critiques of expressionism and abstract art and while his nationalistic writing on the Gothic tainted him as a conservative, his work on architecture and the city affords productive interpretations of the metropolis. So far, however, historians and theorists have viewed his position on the modern city with a fair amount of skepticism. The critical histories of Manfredo Tafuri and Francesco Dal Co targeted Scheffler's alleged "optimism," reading him as protégé of the capitalist Großstadt, while Massimo Cacciari saw Scheffler as an urban romantic aiming at a new synthesis, and Julius Posener interpreted him as an "Anbeter der Macht" (admirer of power). ${ }^{15}$ Most saw in Scheffler's frequent analysis of incompatible elements of modernity a longing for synthesis and an attempt to formulate a new historical continuity. His writings on the metropolis, however, rarely resolve any of the incompatibilities-the one between architectural form and urban formlessness, for example, remained dynamic. On the contrary, Scheffler's ideological dilemma is manifested in the constant tension between irresolvable dichotomies. The writing continuously oscillates between dualisms such as order versus chaos, emptiness versus saturation, purity versus multiplicity, boundary versus margin. In the city of Berlin and the Wertheim department store in particular, Scheffler found a responsive territory on which he saw these modern tensions play out.

"Nowhere," Scheffler argued, "is the character of modern building art-in positive and negative terms-more instructive [than in Berlin]."16 Berlin-Ein Stadtschicksal, his first book to focus entirely on the modern city, sets out to investigate the capital by considering the aspects that it lacked-history, culture, and urban form-in comparison to more established cities like Munich or Dresden. Scheffler saw Berlin's lack of tradition and its blatant acceptance of dominant economic forces as underlying its unconditional devotion to modernity:

The young city of Berlin has none of the juxtaposing characteristics of old and new; instead there is a condition of indifference, which is surely regrettable in regards to the character of the image of the city [Stadtbild], yet it also facil- 
itates other aspects. ... Only the lax and faceless [physiognomielos] readiness to receive everything that is newwhether it be good or bad-allows Berlin's condition to become paradigmatic. ${ }^{17}$

What Scheffler saw in Berlin's condition of "indifference" was twofold: on the one hand, it created an undefined urban image that lacked the sophistication of older cities; on the other hand, it fostered unconditional openness toward modern inventions. Berlin's carelessness about its appearance was the prerequisite for its devotion to everything modern. To Scheffler, the "faceless" city had grown exponentially and with it "grew its formlessness into something fantastical."18 The unplanned, tumultuous, and ever-changing metropolis, which he found most potently in Berlin, was not only propelled by modernization and experienced as modernity but was anticipated to be the source of a modern architecture. In fact, for Scheffler, urban and architectural inventiveness occurred not in spite of the formless metropolis, as illustrated by sites such as the infrastructural concoction of the Gleisdreieck, but "especially because the urban formlessness created room-to-maneuver [Spielraum] for unlimited possibilities.”19 Just as Walter Benjamin would later find that "[the] decay of the aura, in works of art is matched by the huge gain in room-for-play [Spielraum]," so Scheffler hoped to find new possibilities in the formless city. ${ }^{20}$ Both associated the term Spielraum (literally "room for play," but also understood as "leeway," "scope," "elbow room," or "room to move") with additional Denkraum (space for thinking). The so-called planlos (unplanned), inarticulate, and varied sites of the city became the zone in which alternative points of view were able to develop and where new architectural paradigms could emerge. The never-ceasing incompleteness of modernity was, for Scheffler, most clearly expressed in the imminent and always pending urbanity of Berlin. The city that "overnight" had become modern was here seen as the incubator of modernity that "was condemned always to become and never to be." 21

While critiquing Berlin for its unconditional surrender to modern culture, the formless metropolis had created Spielraum in which new building types and materials were to emerge. Sparked not by the novelty of architecture but the provocations of the modern city, architects were asked to study the metropolis, learn from it, and invent architectural forms that could engage this new urban climate. Scheffler's Berlin was the prototypical modern city of asymmetry, difference, and multiplicity: selfconscious about its potentials, unsentimental in its attitude toward culture, obsessive about technology, unapologetic in its taste for progress, ironic about its lack of history, and uncritical yet passionate in its optimism. ${ }^{22}$ Voicing one of the most devas- 


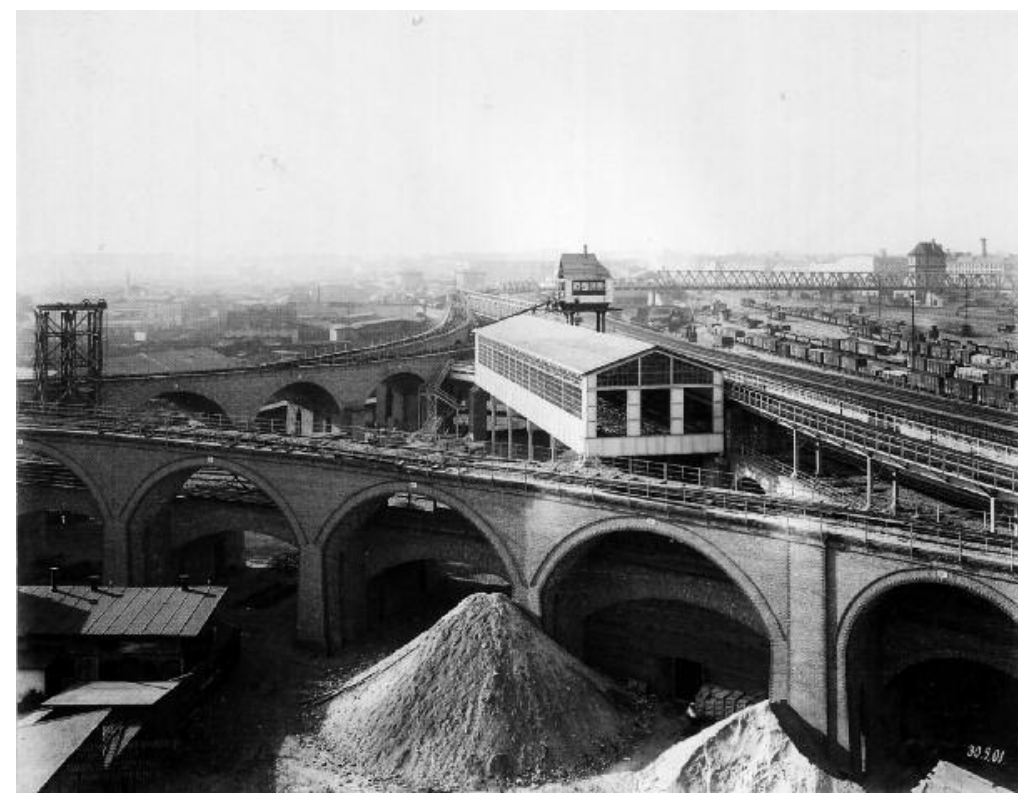

tating critiques of the city, Scheffler was quick to reply that while "unconditional affirmation was impossible, ... resistance to the historically given was equally pathetic." 23 One had no choice but to engage the metropolis, for it presented the only effective position within modernity. He argued that to reject the metropolis would mean to overlook its "unlimited possibilities" and, more specifically, the emergence of a new kind of architecture. ${ }^{24}$

\section{Landscapes of Spectacle}

Berlin's industrial economy had transformed the urban landscape, creating a rapidly growing city that by the end of the nineteenth century became the most densely populated metropolis in Europe. Expansion in trade had not only created a new middle class but made commercial goods and entertainment more accessible for larger parts of society. At the turn of the century, the epicenter of production, consumption, and entertainment in Germany was Berlin, the city the Baedeker travel guide selfassuringly declared to be the "greatest purely modern city in Europe," revolving around money, goods, and services. ${ }^{25}$ For Scheffler, this environment was threatening and fascinating at the same time-threatening because it devalued established cultural, urban, and architectural forms; fascinating because it enabled new paradigms in spatial practices to emerge. The dualism between menace and intrigue came most explicitly into focus when Scheffler studied the department store of Messel—a building type that was new to Berlin. ${ }^{26}$ While New York had witnessed the invention of the first passenger elevator for a store on Broadway and Broome Street in 1857, and the iron-and-glass atrium of Bon Marché in Paris had fascinated its customers since 1887, the department store did not fully arrive in Berlin until the Wertheim consortium opened its store on November 15, 1897. ${ }^{27}$ Closely related to the English term department store, which 
denotes the agglomeration of many shops into a single building, Georg Wertheim (one of the brothers who led the commercial endeavor) used the German term Warenhaus-literally, a "house of goods" for sale-for their new flagship store.

Messel had already designed two stores for the Wertheim brothers and saw this recent development as an opportunity to create a new kind of architecture. Both parties were aware of the impact that the store, in its new location, with its unprecedented size and business philosophy, could achieve, and Messel's response was a confident architecture that formally, spatially, and materially echoed these ambitions. In the first building phase, Messel designed a massive glass façade that extrapolated the shop window over multiple floors and visually joined the turmoil of the metropolis with the tumult on the different retail floors. Giving form to the spatial (urban turmoil), economic (commodity culture), and material (glass and iron-frame) forces of the metropolis, Messel effectively constructed a new kind of interface between the metropolis and architecture. As the city was taken in, it developed in the complex spaces of layered shopping floors, connecting bridges, and high courtyards as urbanism of the interior.

Julius Posener's magnum opus on Wilhelmine Berlin and Frederic J. Schwartz's work on the Werkbund point out how Messel's store "was seen as both the architectural event of the decade and as a definitive solution to the problem of developing a representative architecture specifically for new retail institutions." ${ }^{28}$ But the Wertheim store was not only the event of the decade for its importance in architecture; more significant was its introduction of an urban spectacle to the metropolis. As a new urban institution that gave access to a large number of individuals and provided them with all the essential aspects of urban life, it became understood as a world of its own. From shops, via galleries, to restaurants and photo studios, the Wertheim store imported what metropolitan urbanity had to offer. Only this time it condensed these different worlds into one spatial construct. Emil Claar, a contemporary observer, writer, and poet would describe this collision of different environments as "Die Welt im kleinen" (a world in miniature), the same phrase Benjamin cited from the Illustrated Guide to Paris when speaking of the arcades. ${ }^{29}$

To better understand the department store's inclusivity as an example of a world in miniature that pulled the city into the interior as well as its effective use of urban spectacle, an excursion to Berlin's trade exhibition of 1896 is instructive. Here, importations of different worlds into the exhibition can be seen in relationship to-if not as precursor to-the introduction of the city into the department store. Twenty-five years after the founding of the German Empire, the trade exhibition at Treptower Park marked Berlin's transformation into a world city and docu- 


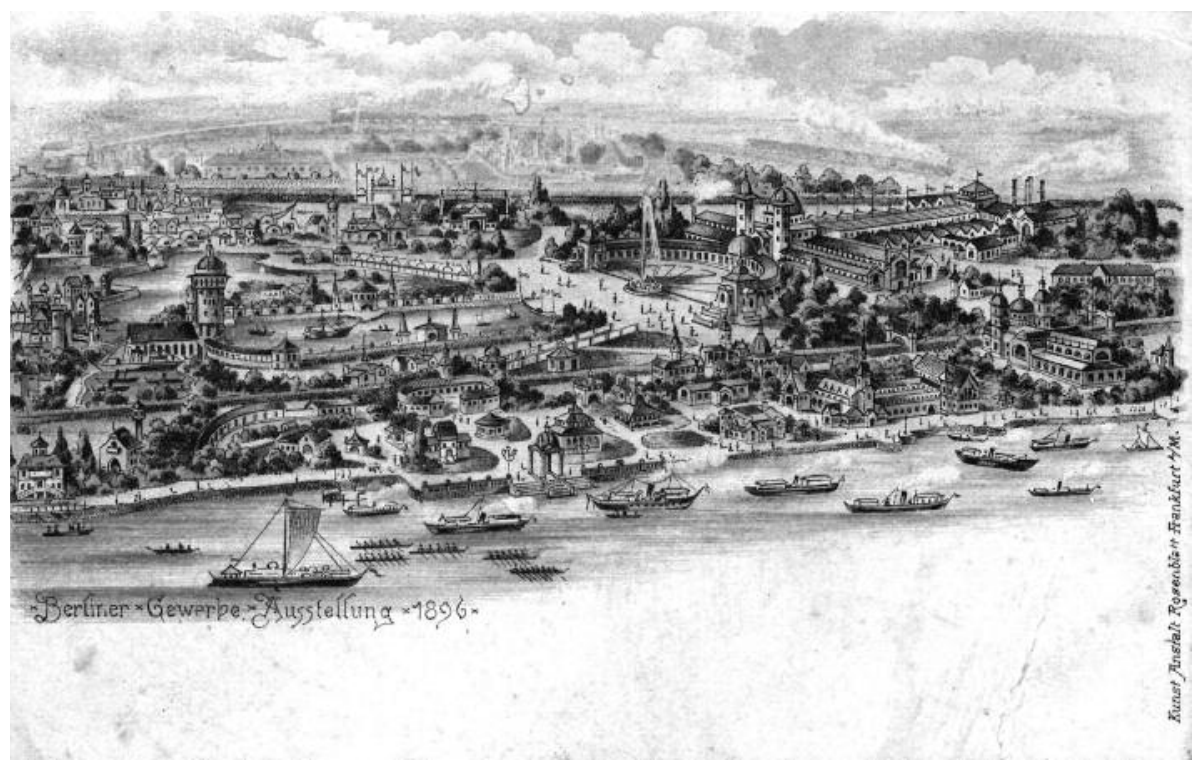

mented the intricate relationship between the market and entertainment. ${ }^{30}$ At the exhibition, the newest commodities were exhibited, in turn crystallizing and accelerating the exchange Postcard showing the Berliner Gewerbeausstellung (Berlin value of goods. Contemporary accounts spoke of the proximity of Trade Exhibition), Berlin, 1896.

goods and spectacle. Commenting from afar, the New York Times, for example, wrote,

Some Berliners . . . criticise the affair already as an exhibit of restaurants and beer gardens merely, with theatres, panoramas, [and] peep shows . . . thrown in as baits to the thirsty and hungry multitude. And it is a fact that the space for Berlin's manufacturers is a mere trifle compared with that covered with structures built for feeling and fun. But the main point is not satisfaction of the mere pride of Berliners in their own swiftly built and ever expanding capital, but the greater enjoyment of the visitor. And that is likely to be the result of a trip to Treptow[er] Park from May 1 to Oct. $15 .^{31}$

The exhibition obscured the difference between commerce and entertainment, encouraging the visitors to indulge or, as Benjamin would describe it, "[creating] places of pilgrimage to the fetish Commodity ... a phantasmagoria into which people entered in order to be distracted." 32 The exhibition grounds were identified as a landscape in which entertainment and commerce blurred together into a fantastic amalgam of spaces that persuaded the visitors to drift and divert through short-lived environments. As such, the exhibit functioned as a condensed version of the flaneur's experience of the city: no longer the leisurely strolling through urban spaces but the confrontation with frequently juxtaposing atmospheres riddled with sensations. Only the department store would exceed the frequency of intensities found on the exhibition grounds.

The temporary nature of the exhibition with the prospect of testing new ideas in a laboratory-like setting sparked the imagi- 


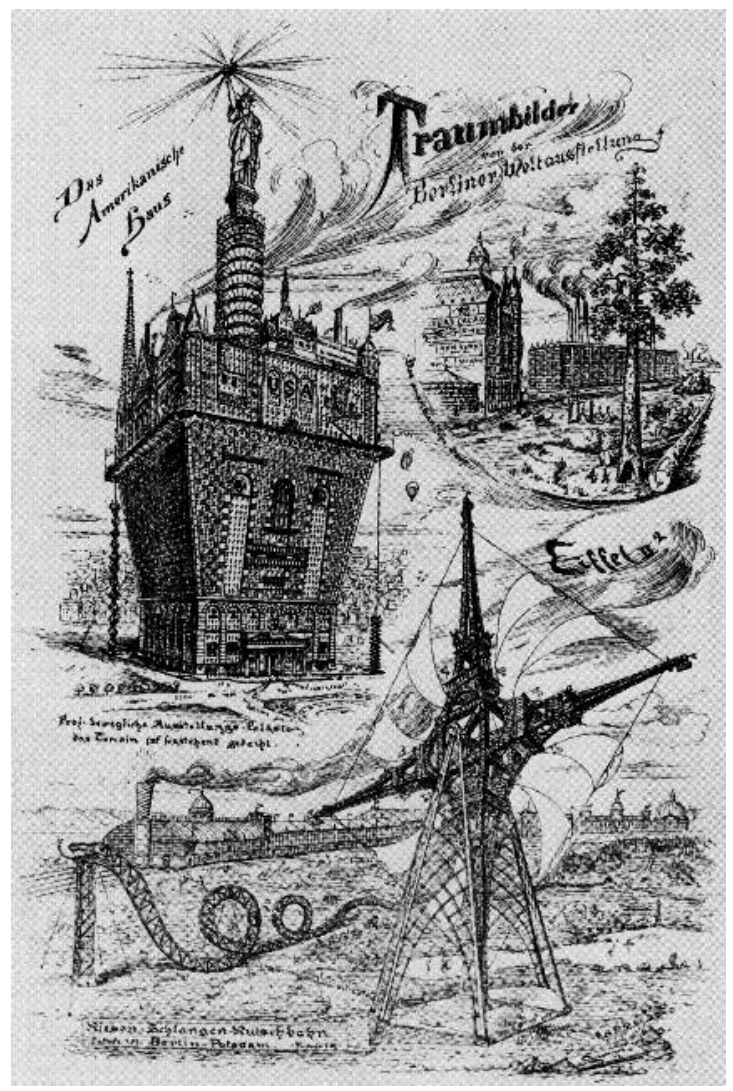

nation of many designers. They sought to foreground unique sensations that suspended the routines and conventions of everyday life. The most eccentric designs, or Traumbilder (dream imagery) as they were illustrated in the newsletter of the Berlin Architectural Association, appropriated existing building types such as the American skyscraper and the Eiffel Tower by exaggerating their inherent characteristics. ${ }^{33}$ A skyscraper, for instance, was conceived as a vertical city topped by the Statue of Liberty, and the Eiffel Tower was multiplied, with four towers serving as the arms of a gigantic windmill, with sails rigged between them. While none of these forecasts were built, they are indications of a spectacular experiential architecture that the department stores would later cultivate and premonitions of what would be theorized as the "city in the city" and the "multi-sided tower." ${ }^{4}$

"Freed from the stipulation of permanence," architects such as Bruno Schmitz, who designed the main exhibition hall, were led to "the conscious denial of a monumental style, ... producing a new and positive shape," according to Georg Simmel. ${ }^{35}$ While amusement was the only "unifying factor" that connected what Simmel called subjective and objective culture, it also produced a diversity of experiences and atmospheres. ${ }^{36}$ The Cairo exhibition, for example, consisted of a replica pyramid surrounded by palms that were planted in the sandy ground of Berlin, made to resemble Egypt. ${ }^{37}$ The simultaneous straightforwardness (when importing foreign architectures) and naïveté (when implementing them) would not only engage the emotions of the visitors but construct alternative worlds, simultaneously alien to Berlin and estranged from their original settings, yet "at home" in both. In essence, the environments belonged nowhere and could be adopted without being absorbed. The exhibition was a laboratory where saturated environments were tested-environments whose promiscuity necessitated the suspension of disbelief and encouraged indulgence.

For Berlin, the mixture of spatiomaterial absurdity and shortlived architectural experiments during the exhibition presented a new architectural paradigm that allowed for spectacles and questioned longevity. The department store was receptive to this new architectural blend. Just as nineteenth-century expositions incorporated the world and sought to appropriate its varied atmospheres, so did the department store incorporate the metropolis; it stacked the temporary environments generated by the 
trade exhibitions and configured them into a multilevel experience of shopping that was driven by the permanent presentation of commodities and the uninterrupted flow of consumers.

\section{Interior City}

The department store was a product of the nineteenth century in which new production quantities came to coalesce with an accelerated consumer culture. But, even as the Warenhaus typology had no explicit forerunners, the development of these large interiors did not arrive overnight. Benjamin, in his unfinished Passagen-Werk (Arcades

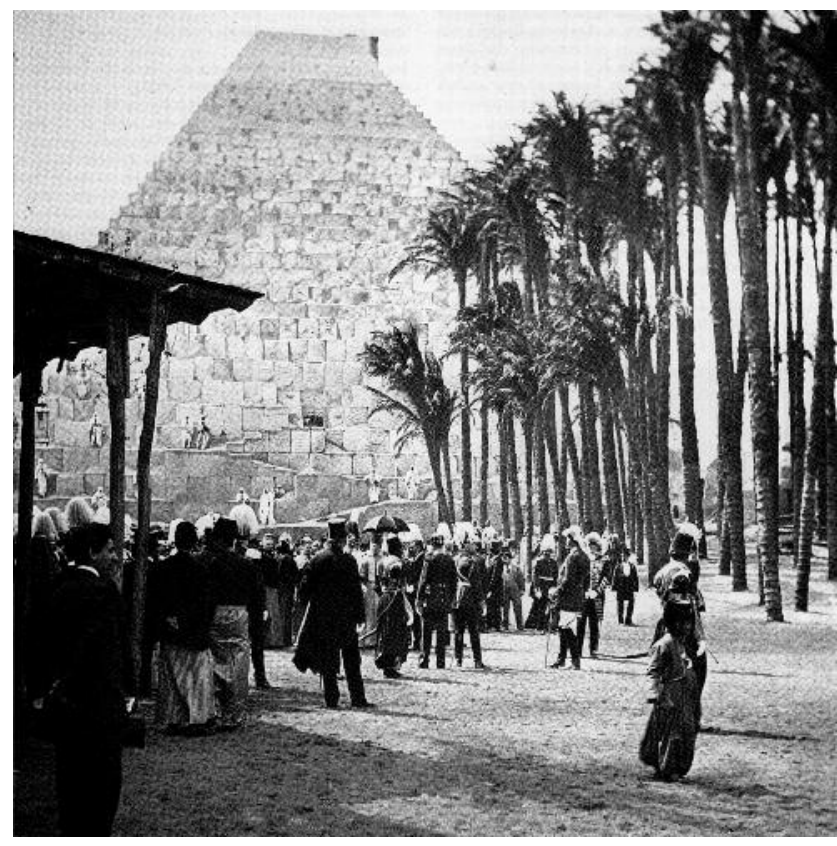

Project), elaborates on the evolution of the department store from the shop in the arcade and as a realm in which the consumer begins to consider him- or herself as part of the mass. From the city as a landscape to the city as a room, "the department store ... puts even flânerie to use for commodity circulation." ${ }^{38}$ Modern shopping had come a long way and was closely associated with such nineteenth-century forces as urban population growth, the proximity of public and commercial space, the mass production of goods, the increasing division between producer and consumer, and the use of new materials. Street-lined shop windows had already amplified the spatial effects of commodity culture in the city, where one no longer had to enter a store but was invited to stroll past goods that were publicly displayed in streets such as the Rue de Colonnes (1793), which combined an Italian arcade street with the commercial concentration of Paris. Here, strolling and shopping could take place in any weather.

Along with the growth of the commercial sphere came the interiorization of the city-a development that was continued by the Parisian arcades at the beginning of the nineteenth century and culminated in the early department stores later that century. The use of glass and iron was of pivotal importance, because lighter construction enabled larger shop windows for the presentation of goods and the legendary glass-roofed interior streets that cut through city blocks. While arcades such as the Passage Delorme (1808) emulated and interiorized pedestrian streets, the 1820s also brought the enlargement of these interior spaces as glass-covered courtyards and markets in the center of urban blocks. The new lightness and transparency of such locations as the Bazar de l'Industrie (1827) and the Galeries du Commerce et de l'Industrie (1837) was outdone only by Joseph Paxton's building for London's World Exposition in 1851, rightly named "Crystal Palace.”39 

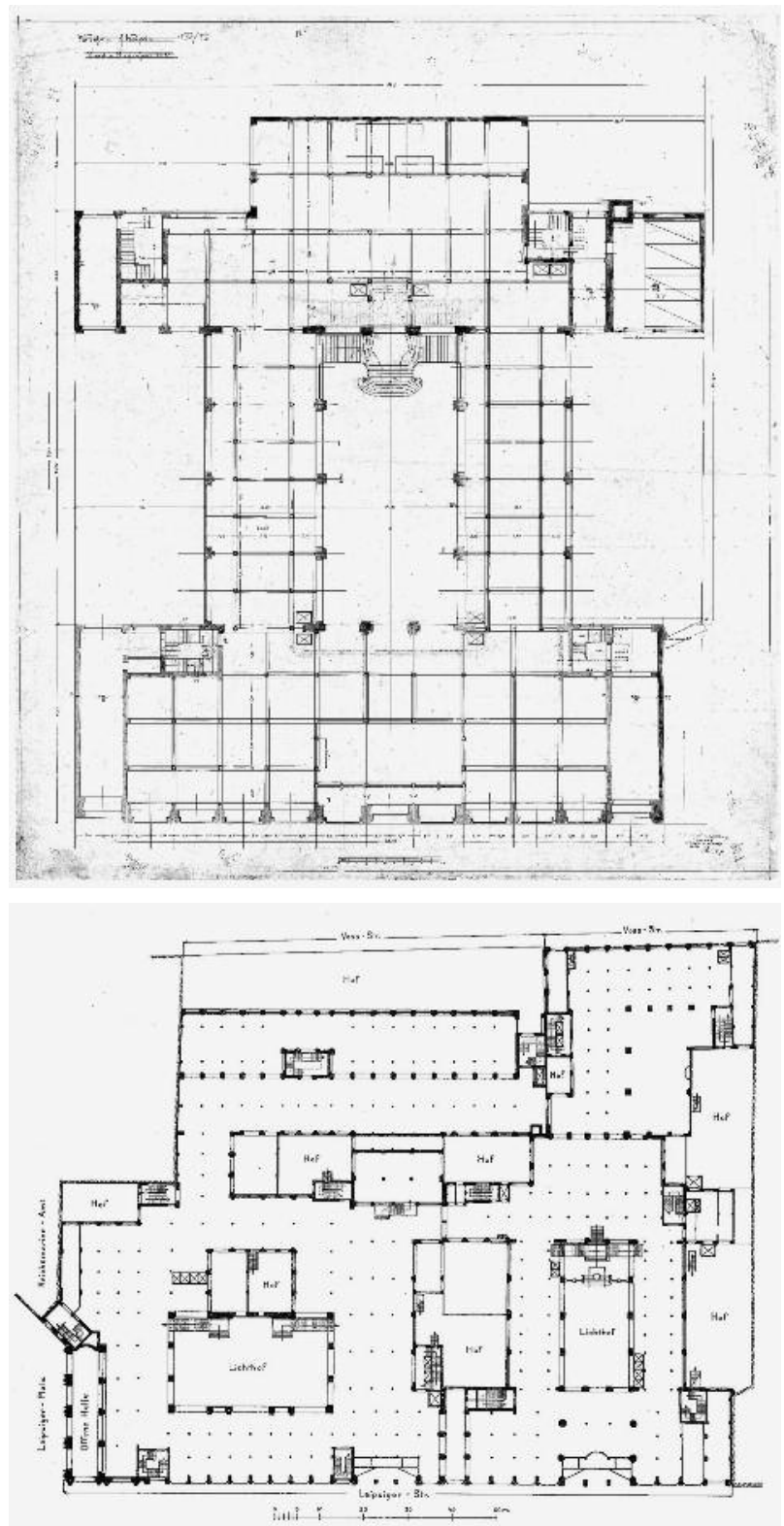

The spatial development of retail architecture can be understood as an incremental engulfment: from shops, lining the perimeter of the block, via the extension of these spaces into arcades, to the eventual occupation of the entire urban block by the department store. While the interiorization of the city appeared in the arcades, only the department store conceived of the entire urban block as an entity. Over the duration of the nineteenth century, the specialized terrain of shopping (designed to handle large crowds demanding mass-produced goods) displaced the existing diverse urban block, which was composed of housing, retail, and even manufacturing. The expansion of the Wertheim Warenhaus was a dramatic display of this historical development. Moving to its final location in 1892, the Wertheim store started by renting four stories of a building at Leipziger Straße 111 for its flagship store, and only four years later asked Messel to design its expansion. ${ }^{40}$ The first building stage, which included an unprecedented glass façade as well as a large glass-covered courtyard, was soon superseded, with the floor space more than tripled and arranged around two large and six small additional courtyards in the final stage.

While Messel is often read as a transitional figure within modernism, many architects of the coming generation viewed him as visionary because of his innovations in department store work. Peter Behrens, while acknowledging Messel's historicist roots, lauded his ability to fuse styles within a modern framework, and Bruno Taut was "captivated by [the store's] clarity and dignity." ${ }^{11}$ Unlike these younger architects, Messel was less at ease with his own design. Conceiving the flagship store in the year when he strolled through the Berlin Trade Exhibition (1896), he was startled at the sight of his invention one year later. As one of his contemporaries recalls, "[he] was deeply shocked when he saw emerging the naked pillar system of the Wertheim façade." ${ }^{42}$ Unintentionally creating a new building paradigm that its creator no longer recognized, Messel was baffled and maybe even frightened by the 
scale, transparency, porosity, and complexity of his newest design-a kind of architectural "outcast" that perfected the instrumentalization of technology and the spatialization of commerce. Already in 1900, Berliners would witness the extrapolation of Messel's radical façade when the Tietz department store, designed by Bernhard Sehring, opened its doors. While Messel's conflicted relationship to his work is implied in his avoidance of the same openness for later façade designs, Sehring conceived a seemingly freehanging prototypical curtain wall that minimized subdivisions. What Messel's façade had set in motion became now a most explicit instrument for department store architecture. But perhaps it was less the alliance with commerce than the shifting role of design that unsettled Messel. He might have seen the Wertheim façade as an artifact of his loss of control over the design and construction process and his frustration with the forces of modernity, which required surpassing previous aesthetic considerations and adopting a more rational design procedure to address the demands of this new building type. Commercial and programmatic stresses had produced an organizational construct that abbreviated artistic gestures while amplifying the conditions of the department store as an instrument for shopping.

Whereas Messel lamented the pragmatism that the Wertheim Warenhaus required, Scheffler insisted that the modern metropolis provoked it, thereby forcing the emergence of a new building style. Of all cities in Germany, he argued, none was more committed to modernity than Berlin. While the city had little in common with the other, centuries-old capitals of Europe, it shared many characteristics with cities in the United States, and Messel's Warenhaus was one of the most vivid expressions of this Americanism. ${ }^{43}$ Whereas the earlier department stores in Paris had installed large shop windows at the ground floor, their much more introverted upper façades still conformed to the conventions of urban architecture of the nineteenth century. Architects and developers in the United States, however, more openly embraced the use of iron construction. In the 1850s, for example, New York saw an entire district built in cast iron (Soho), and Chicago after its fire in 1871 also demanded a rethinking of building materials. Here, in William Le Baron Jenney's First Leiter Building of 1879 and later in the works of Louis H. Sullivan and Dankmar Adler, the vertical organization of the exterior surface bridged multiple stories with the help of the steel frame. 


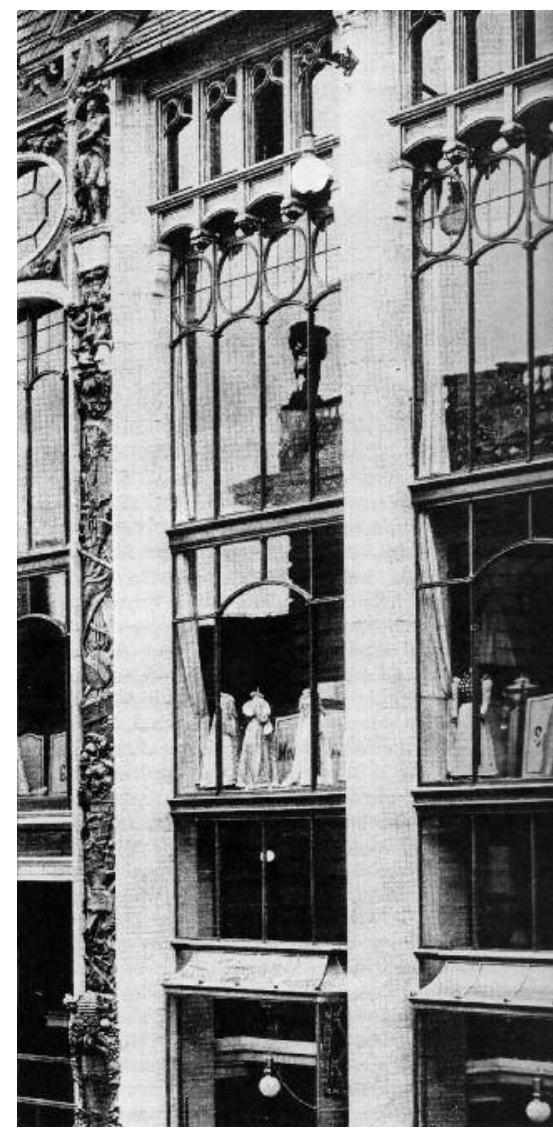

The similarities between the façades of the Chicago School and Messel's Wertheim Warenhaus did not pass unnoticed in the German press. Writers frequently noted "the many links to" what was called "American style." 44 The city of Berlin around the turn of the century had already been described as the most American of all European Cities. Walther Rathenau, in his ironically titled essay "Die schönste Stadt der Welt" (The most beautiful city in the world), summarized Berlin in the now famous words, "Spree-Athens is dead and Spree-Chicago develops." 45 The essay, one of the most critical explorations of how mechanization had transformed modern Berlin, paired harsh criticism of the existing environment with a determined affection for progress-the latter, always associated with the United States. Only a few years later and equally dramatically, Scheffler criticized "Berlin's Americanism" by describing the city as "the capital of all modern ugliness" and noting its willing embrace of modern economy, industrial culture, and fast-paced urbanity. ${ }^{46}$ Yet this Americanization of Berlin, he also explained, "forced ... [Messel] to find a clear and monumental expression of the spirit of the new time." 47 Speaking more explicitly to the Wertheim building's façade, Scheffler wrote in Moderne Baukunst (Modern building art) in 1908, "The sight of the façade frightened even the most courageous ... but its logic was disarming. Stone and iron were finally accepted as materials for retail buildings, the separation into different floors disappeared, [and] the soaring pillars created a unified whole." ${ }^{48}$

For Scheffler, the Wertheim Warenhaus was the expression of a new architecture that, unlike any other, embedded itself within the modern city and was perfectly equipped to fulfill the demands of the metropolis. Opening the entire façade as a glass surface divided merely by widely spaced piers not only offered to passersby on foot and in vehicles an unapologetic view of the interior, devoted to shopping, but also exposed the city's speed to those who looked out from the vantage of the shopping floors. The pillar system that vertically joined all stories (which had shocked Messel and "frightened . . . the most courageous") opened a large window into both worlds-the city and the store-exposing the building's function and the city's turmoil..$^{49}$ On opening day, the first shoppers witnessed from the inside what local newspapers described as a massive traffic jam on the Leipziger Straße, created by a crowd of amazed passersby, whose gazes were drawn into the shop interior.

A contemporary description of the glass façade comes from Paul Göhre. In 1907, Göhre, a theologian and later politician and 


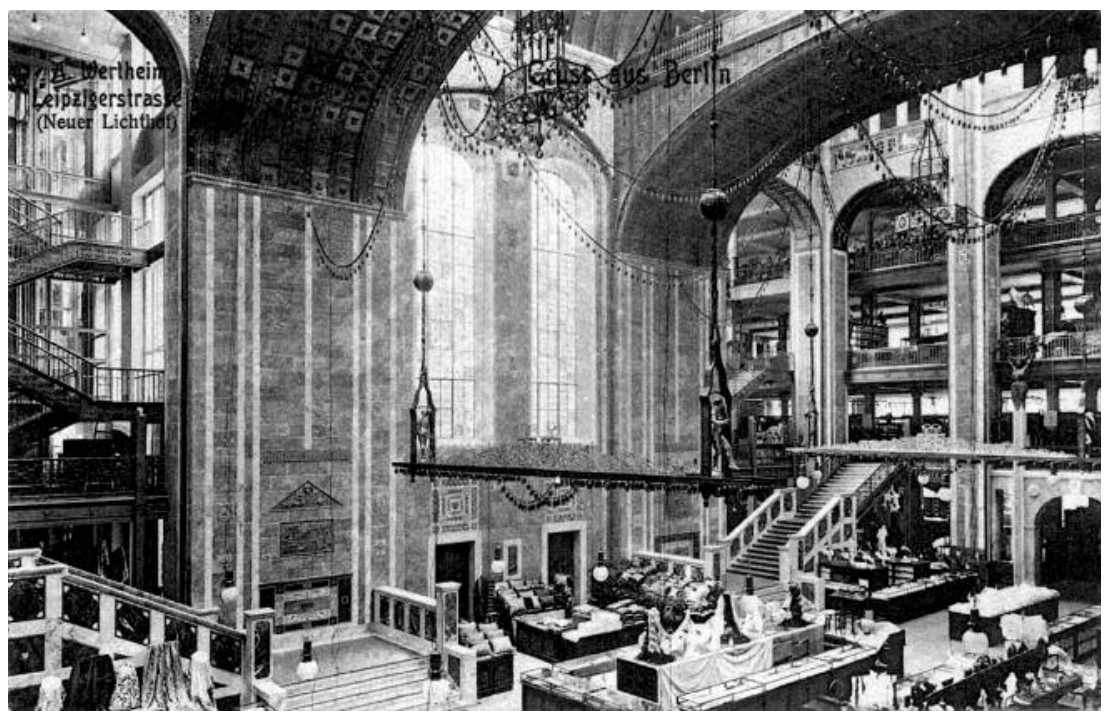

ally of Friedrich Naumann, spoke of a wall of glass that advertised the interior and opened all floors to views from the street: "The entire interior with its masses of goods, masses of shoppers, and flocks of sales personnel is fully revealed to the passerby." 50 What struck Göhre and Scheffler alike was that the reciprocity between inside and outside went far beyond a conventional visual exchange. The spatiality of both realms was influenced. The city was subjected to the spectacles of the shopping interior, and the interior was infused by the dynamics of the city. Widely circulating textbooks on architecture took their cues from the Wertheim store and went so far as to describe department stores by analogies to traffic and pedestrian flow: "[Warenhäuser] should be spacious and manifold ... and at the same time should be able to accommodate large pedestrian traffic without congesting the building or [even] endangering its users. . . . [When accomplished] this building will easily emerge as an architectural highlight." 51 The traditional boundary between city and interior was questioned through a new reading in which the interior essentially belonged to the city. The ether of the metropolis had fully penetrated the interior of the urban block, letting a new kind of urbanism emerge, an urbanism of the interior. While the rhythm of the façade registered the speed of the metropolis, the complexities of the city were captured in the interior spaces of the store.

Designing multiple routes through the space in order to facilitate easy access, Messel connected the interior spaces with bridges that crossed the courtyards at the upper levels. He heightened the spatial complexity by designing adjacent bridges at different sizes, by means of this perspectival trickery suggesting a depth that exceeded the dimensional possibilities of the building. Posener compared this spatial impossibility with Piranesi's Carceri, where subterranean vaults, stairs, bridges, and machinery invent a realm of layered complexity. ${ }^{52}$ What Posener calls a "spatial exaggeration," the Wertheim store delivers with similar
Opposite: Alfred Messel. Wertheim Warenhaus, Berlin, ca. 1898. Detail of exterior façade, first building stage. The glass façade gave unobstructed views into the store (advertising its goods to the city) and visitors of the interior saw the movement of the street as backdrop. Photo: Landesbildstelle Berlin, Berlin.

Above: Alfred Messel. Wertheim Warenhaus, Berlin, ca. 1900.

Postcard showing interior view of second building stage with large light-court. 

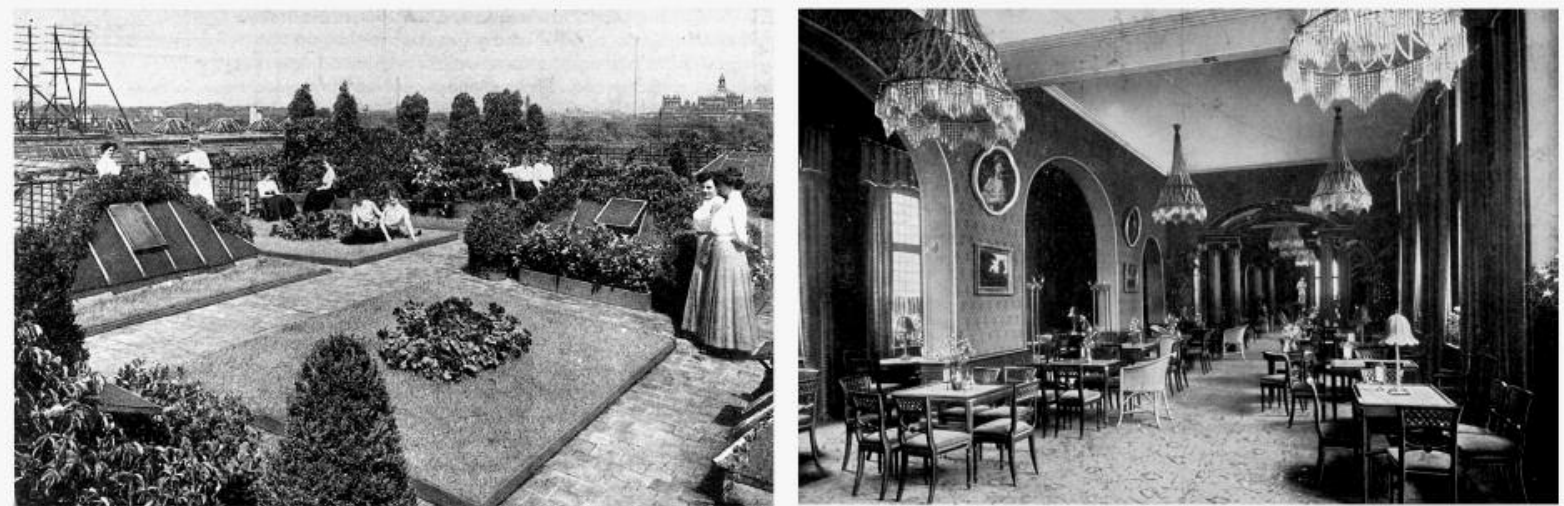

Above and opposite, top: Alfred Messel. Wertheim Warenhaus, Berlin, ca. 1900. Photographs of the roof terrace, the tearoom, the specialty department, and the winter garden. Photos: Architekturmuseum TU Berlin, Inv. Nr. 42647.

Opposite, bottom: View from Potsdamer Platz toward Leipziger Staße, Berlin, 1900. The Wertheim store, appearing in the far distance at the center of the upper part of the photograph, was part of the gateway into Potsdamer Platz, one of the most trafficked urban spaces in Berlin. elements but draws from the modern city. The delirium of the metropolis brought about by the acceleration in all areas of urban life was here associated with the experience of shopping, making it part of the "everyday" within what Simmel had called the "fragmentation" of modernity. ${ }^{53}$

The shop was the backdrop on which other programs were projected. It offered a roof garden for relaxation, a library, an art gallery, a tourist information center, a photo studio, a theater ticket agency, and several restaurants-catering to different types of metropolitan individuals in addition to the shoppers. Here the flaneur, the tourist, the employee, the intellectual, the detective, and the collector would all feel at home. ${ }^{54}$ The Wertheim Emporium thus earned its position as the first address in the Baedeker Travel Guide, which noted that the store "well repays a visit [and] no one needs to make any purchase." ${ }^{55}$ Berlin für Kenner (Berlin for connoisseurs) is even more blunt: arriving in Berlin, all visitors should go to the Wertheim store, where one would "get one's first taste of the tremendous whirl of city life."56 While one might have expected that formal examples of historic or cultural monuments such as the Brandenburger Tor would be recommended as the initial stop for tourists, the Wertheim Warenhaus was endorsed as the starting point for visitors to the metropolis. The department store by some measure had surpassed the metropolis in its capacity to fascinate. The interior city of the store was more Berlin than any real street, traffic intersection, or plaza could ever be. The store became the perfect extension of the oversaturated city. Here, traffic jams could be simulated, light and sound effects tested, engineering works realized, trends instigated, dreams stimulated, and desires satisfied.

\section{Metropolitan Architecture}

For some critics, however, the Wertheim store's interior pandemonium did not go far enough. Scheffler criticized the excessive use of different materials and ornamentation and argued instead for interiors in which "the hustle and bustle [Treiben und Wogen] around the shopping counters would become the ornament [of the department store interior]." ${ }^{57}$ As shoppers and sales personnel would roam between the displays of goods at different speeds, 

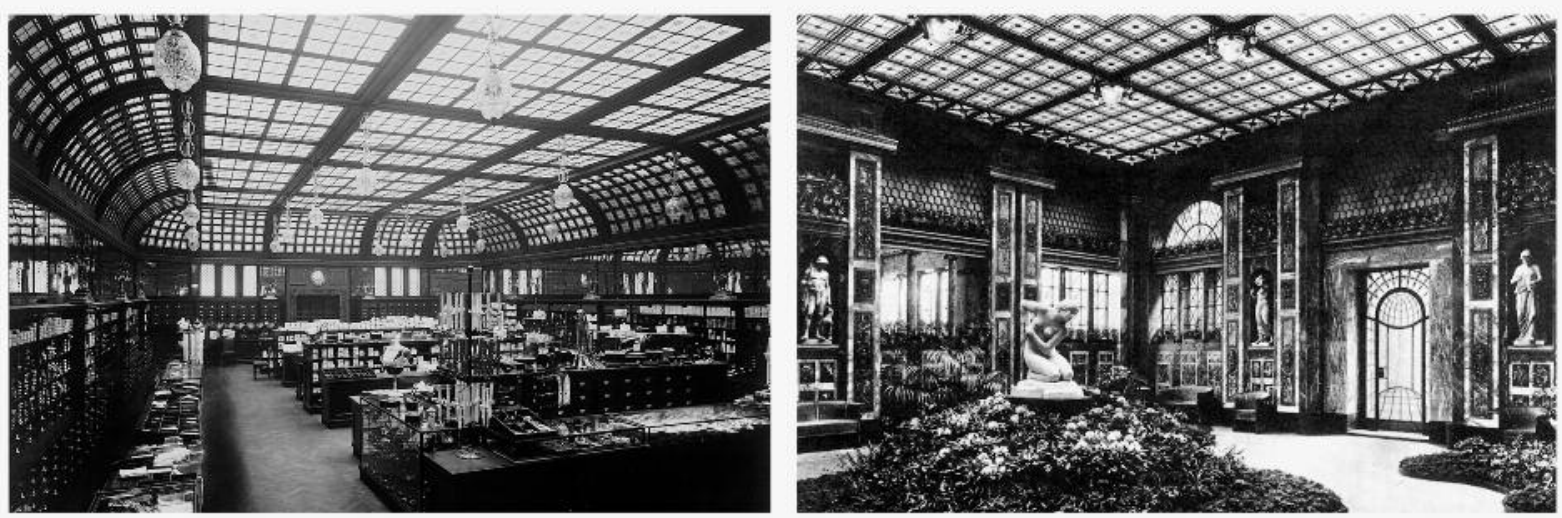

cluster in some areas and disperse in others, Scheffler saw that these movement patterns alone were able to embellish the space. For him, the transitory effects commonly associated with life of the modern city were to facilitate the imagining of an architecture for the metropolis. Movement (slow or fast) was no longer to be limited to the crowded streets but was to enter the department store through the streams of consumers who explored the different floors. Police reports even indicate that the shopping public frequently congested locations such as the staircases, which had to be cleared by the police who in turn

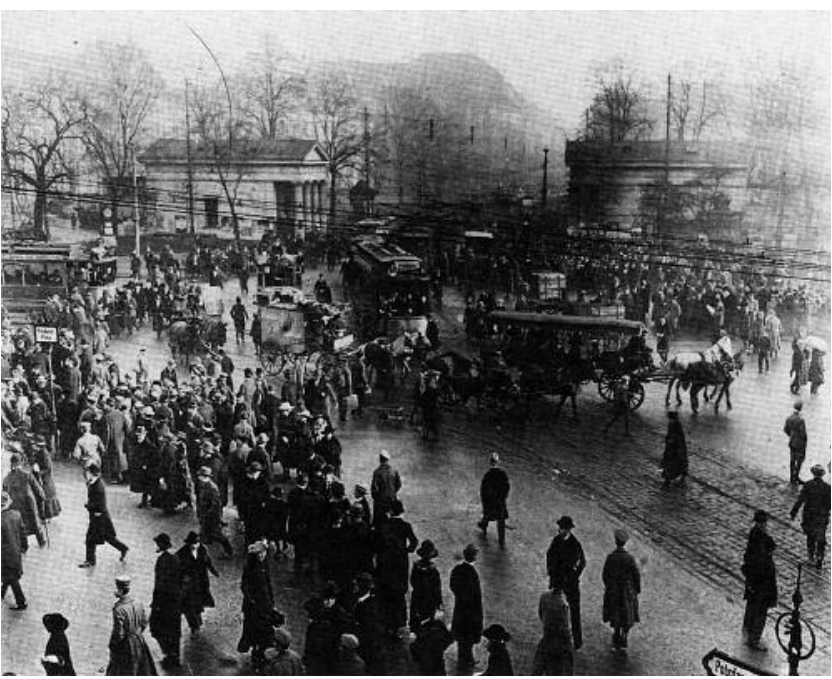
fined the store for overcrowding. ${ }^{58}$ This fluid ornament of pedestrian flow-as opposed to coordinated "mass ornament"animated the spaces. The "restless movement" of Robert Musil's Mann ohne Eigenschaften (Man without Qualities, 1930-1942) would here already enter the store and complete Walter Ruttmann's Sinfonie der Großstadt (Symphony of the Metropolis, 1927).

While Scheffler's fantasy of an interior that would celebrate the movement of shoppers was never fully satisfied (as the lush detailing and cacophony of forms that was associated with the representation of goods obscured the readability of pedestrian flow patterns), he had to acknowledge that the store's interior had long become part of the city. The fluid interweaving of interior and exterior through a new scale of transparency and reflectivity that was later thematized by figures such as Sigfried Giedion was in the façade of the Wertheim store already in full swing. Berlin für Kenner told visitors to return to the scene in the evening. Standing on the upper deck of the number five omnibus, one would pass the store and "experience the incredible vision offered of a mass of people in motion, of lights and speeding vehicles."59 Here, the distinction between the city and the store collapsed into an amalgam of forms and effects by merging the movements 

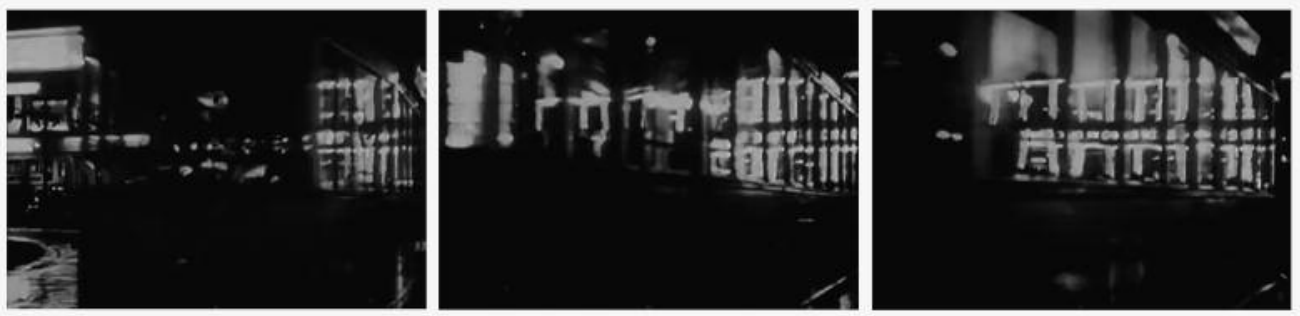

Walter Ruttmann, dir. Sinfonie der Großstadt (Symphony of the Metropolis), 1927. Frame enlargements. The film documents a day in the life of the metropolis of Berlin and the camera frequently shows store windows and scenes of department stores, including the Wertheim Warenhaus. and lights of the interior with those of the traffic outside. Not only did the store reproduce the metropolis in the interior, but it, in turn, spilled back into the city through its material effects. The store's reflective glass façade, the illuminated interior, the regular spacing of the pillars, and the movement of shoppers also became tonic to the city in motion.

Scheffler understood this fusion of speed, spatial complexity, and play of materials and light as the driving force behind what he called a "metropolitan architecture." 60 The understanding of the city as essential for architecture sets this modern project on a very different course from more well-rehearsed models. Unlike Hermann Muthesius, for whom modern expression was first and foremost a tectonic understanding of purposeful forms, Scheffler believed that modern architecture was deeply rooted in the dynamics of the modern city. As the department store had been, so were all modern buildings to be developed from within the metropolis. And Messel exposed, even if reluctantly, modernity within architecture: "[He] was the first German architect who understood the nature of the metropolis.... Where his academic colleagues used stylistic lies to cover up the metropolitan elements, he attacked the metropolitan problem at its core. He has given a new beauty to the new necessity/matter-of-factness [Notwendigkeit] of our time." ${ }^{11}$ For Scheffler, the Wertheim store's emergent forms derive from the multiplicities of urban chaos, giving a new expression to the fractured and formless modern city. Here, metropolitan architecture became understood as a product of the modern city that, as a miniature city of its own, was able to cultivate new forms of urbanity, which could leak back into the city at large.

Scheffler argued that the effects of the Warenhaus on the city would be vast if pursued. A new metropolis would see individual shops consolidated into Warenhäuser, which would be found in every district of the city. Problematizing the erosion of civic life and the family as "ur-cell of the city" in particular, Scheffler sought a new urban image. "In the metropolis, the mass of population was in danger of simply becoming an infinite number of individuals." 62 Aiming at a new city that was metropolitan and civic at the same time, Scheffler highlighted the importance of new building types emerging from the metropolis. He argued that these new types, associated with a new scale, program, and urban character, would give a new consolidated form to an otherwise formless and disorganized city. He observed that they had become particularly visible now, at a moment of transition, when they 
stood in contrast to the disarray of the metropolis.

Identifying new paradigms not only in the department stores but in the storage houses and unfinished/unadorned apartment blocks, Scheffler noted that the impersonal and typical came more and more into the foreground, intuiting a new architectural form, defined by large scale, homogeneous surface treatment, and urban continuity. ${ }^{63} \mathrm{He}$ found hints of a metropolitan architecture in the retail houses of Behrens, the urban villas of Endell, the public institutions of Ludwig Hoffmann, the houses of Muthesius, the monuments of Hermann Obrist, and the homes of Heinrich Tessenow. The anonymity of the metropolis, within what Simmel would call “objective culture," had provoked a new architecture. For Scheffler, this became most explicit in the Wertheim Warenhaus expansion until $1906 .{ }^{64}$ In only one decade, the Wertheim store grew from Leipziger Straße toward and eventually into Leipziger Platz, adding and assembling a collage of spaces and courtyards behind a regular façade that wrapped its perimeter. Applauding the way in which the façade had become a continuous element, creating a unified building block and accommodating the speed of the metropolis, Scheffler saw its uni-
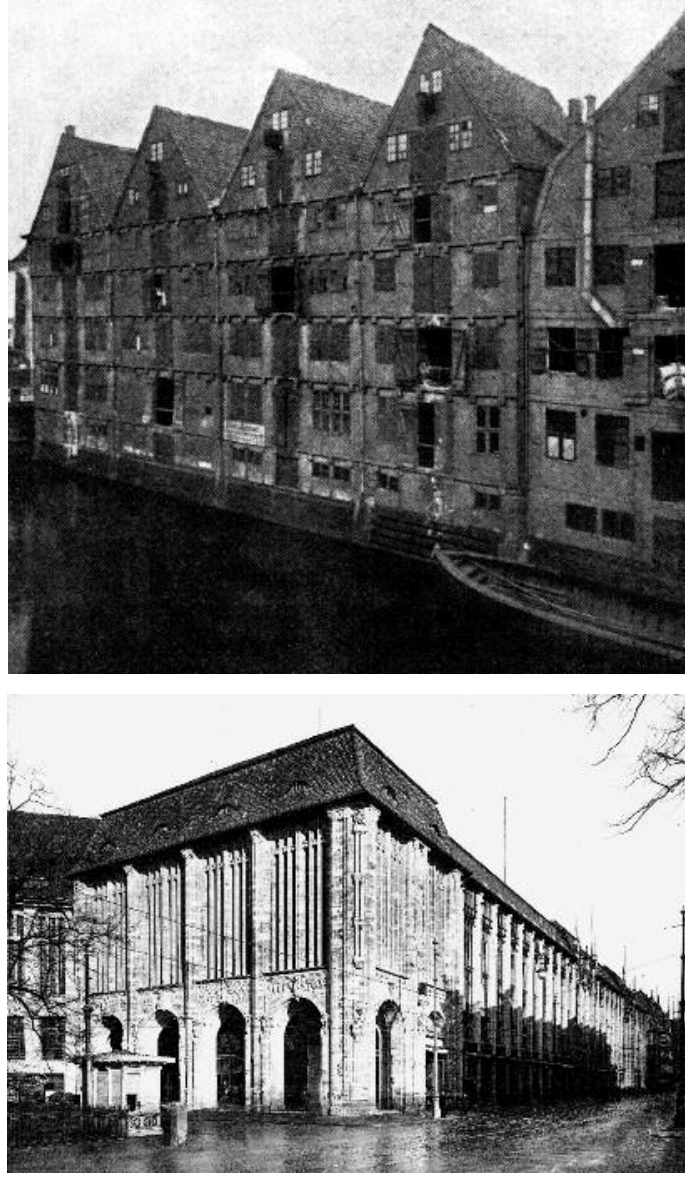
formity as a means for architecture to withstand the formlessness of the modern city. ${ }^{65}$

Developed in buildings such as the Wertheim Warenhaus, theorized by figures like Scheffler, and promoted by critics such as Walter Curt Behrendt, the notion of the continuous façade entered the architectural discourse. Behrendt, who in 1927 would declare the "Victory of the New Building Style" (Der Sieg des neuen Baustils), had in 1911 completed a dissertation that he dedicated to Scheffler. ${ }^{66}$ Titled Die einheitliche Blockfront als Raumelement im Stadtbau (The street wall as unified spatial element in city building, 1911), it announced the emergence of an urban architecture of large continuous surfaces that would encompass multiple individual buildings and promote the city block as the new unit for metropolitan space. Scheffler, too, would argue that "individual buildings would be absorbed blocklike so that large building units emerge, limited only by the four surrounding streets." 67 This kind of annexing of multiple buildings or sites within the city and its unification into one superblock architecture required massive investments of capital, dramatically changing the makeup of commerce in the city, 

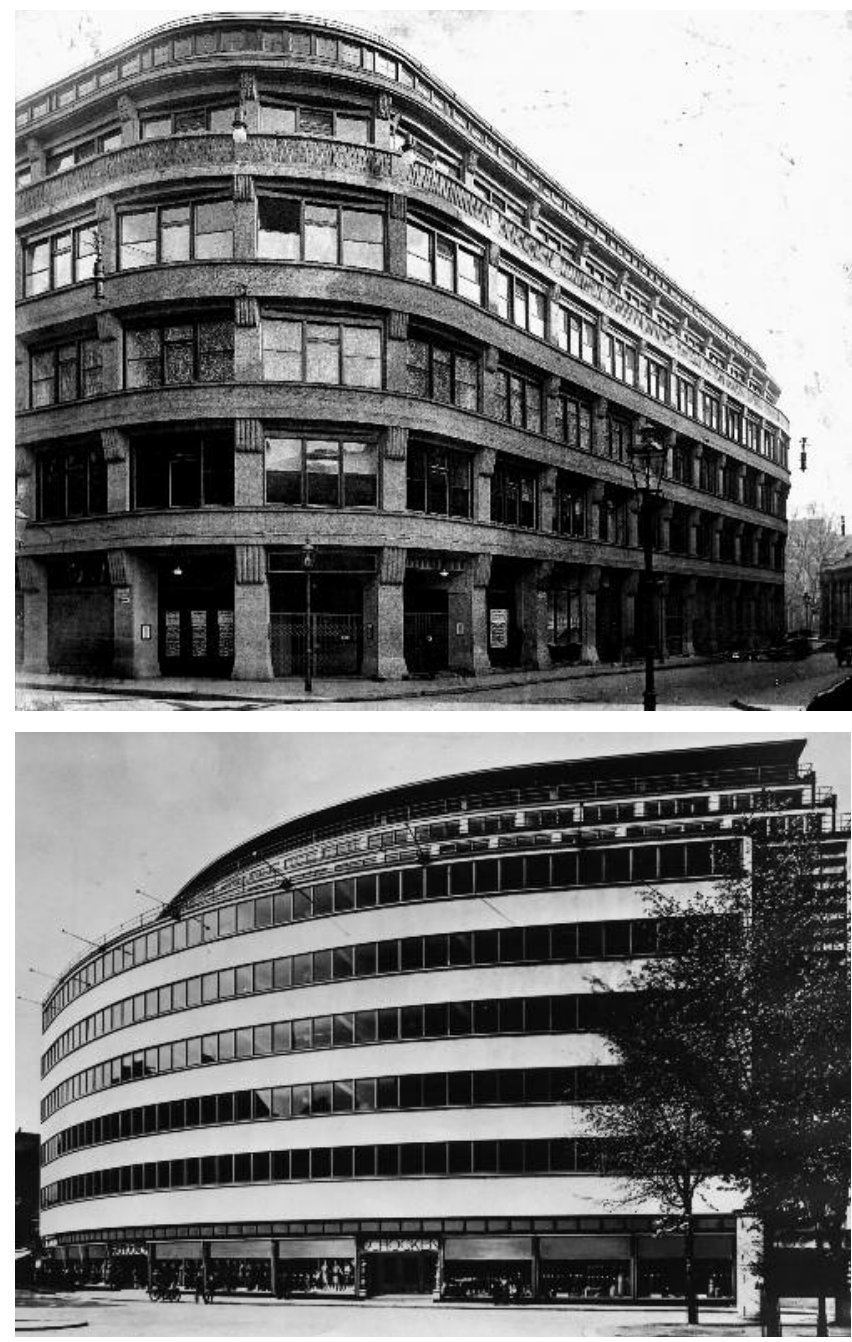

which would become increasingly monopolized and steered by large corporations. But the Wertheim Warenhaus and the subsequent generation of department stores also reveal that this development did not automatically mean architectural impasse but fostered a particular engagement with contemporary forces that resulted in architectural innovations. ${ }^{68}$

In the decade that followed the completion of the Wertheim Warenhaus, numerous architects developed projects for unified megablocks. In 1910, Taut submitted his plans for an expansion of the Warenhaus that sought to continue the façade while heightening its verticality. ${ }^{69}$ The following year, Hans Poelzig designed a fluid architectural façade for the Geschäftshaus (Retail House) on the Junkernstraße in Breslau that continuously wrapped urban space. Echoing this fascination at the Werkbund conference of 1914, Behrens called for architectural forms that responded to the increas-

Top: Hans Poelzig. Geschäftshaus (Retail House), Junkernstraße, Breslau, 1911. Exterior view, ca. 1913. Photo: Architekturmuseum TU Berlin, Inv. Nr. 2632.

Bottom: Erich Mendelsohn, Schocken Warenhaus, Chemnitz, ca. 1930. Photo: Arthur Köster. Bpk, Berlin / Kunstbibliothek, Staatliche Museen, Berlin / Art Resource, NY. ing speed of the city, an architecture that would result in uniformity and large surfaces. ${ }^{70}$ This message was passed on to architects such as Erich Mendelsohn, whose smooth-faced superblocks seemed to extend the city infinitely with an architecture that "appreciate[d] and collaborate[d] with the forces of movement." "11 On the one hand, these uniform and uninterrupted building fronts addressed the dynamism of the metropolis; on the other hand, their seamless urban façades fulfilled one of Scheffler's requirements for a modern city. ${ }^{72}$

\section{|l||}

Scheffler, who saw modern architecture as intimately related to the modern city, and Messel, who designed buildings for that city, established the grounds on which later generations of architects would develop their theories on the relationship between architectural form and urban formlessness. For Scheffler and Messel, the metropolis was a problematic but unavoidable product of modernity, and it was the environment in which a modern 
architecture had to evolve. Their view of the modern city acknowledged the overwhelming power of the market economy on the one side, as well as the emergence of new forms of architecture within a formless urban realm on the other side. Positioned between the revolutionary and the conservative mentalities of the time, Scheffler's writings and Messel's architecture evoked possibilities that could be discovered within the market economy and amid metropolitan turmoil, exploring new opportunities in urban conditions that were commonly seen as constraining or overpowering. They saw as inevitable a new metropolis that conservatives and revolutionaries alike sought to resist. By recognizing its potentials, Scheffler and Messel occupied a place that would become highly contested as architects on both sides sought to theorize the city. Their works are instructive as documents of modernity and alternative readings of the modern city. But, more important, they demonstrate a strategic choice to work from within what they considered to be problematic-a deliberate operation that holds many lessons for architecture today. For one, it points at a new architecture-city relationship beyond resistance or embrace-a condition that can be of particular importance in our current age of extreme urbanization as it proposes to enter into the contested realm of the city. Critical distance would here be substituted for embedded criticality, which operates from within and is, therefore, able to underwrite, divert, or deflectthat is, a metropolitan architecture poised to engage the forces of the contemporary world. 


\section{Notes}

Research on this topic was originally compiled during my dissertation, "The Formless Metropolis” (University of Pennsylvania, School of Design, 2008), which was supported by the Graham Foundation, the Kress Foundation, and the Mehlhorn Fund. The first to comment on the material presented in this essay was Detlef Mertins, and I am particularly grateful for his illuminating insights and the memories of these years. I would also like to thank Iain Boyd Whyte and Volker M. Welter for their comments on an early draft, as well as the editors at Grey Room for their input and pointed questions.

1. Karl Scheffler, Berlin—Ein Stadtschicksal (Berlin: Fannei und Walz Verlag, 1989), 197. Berlin—Ein Stadtschicksal was first published in 1910 by E. Reiss (Berlin). This text as well as the other books and articles by Scheffler mentioned in this article have never been translated into English but have been republished multiple times in German. Translations are my own unless otherwise indicated.

2. Karl Scheffler, Moderne Baukunst (Berlin: Julius Bard, 1907); and Karl Scheffler, Die Architektur der Großstadt (Berlin: Bruno Cassirer, 1913).

3. Karl Scheffler, "Die Großstadt," Die Neue Rundschau 21 (1910): 881. "The location where the struggle for a new architecture must be fought is the metropolis ... because the metropolitan cities, as the centers of modern civilization, create the new presuppositions of a profane and ideal kind of architecture.... It is this spirit of the metropolis [Großstadtgeist] that builds the new architectural structures [Architekturkörper]."

4. Messel was involved in three buiding phases of the Wertheim store: its first iteration at Leipziger Staße (1896-1897), the additions along Leipziger and Voßstrasse (1899-1900), and the expansion toward and into Leipziger Platz (1904-1906). The last phase of extension was build by Ludwig Hoffmann during the Weimar Republic. The building was destroyed during World War II.

5. Ludwig Hilberseimer, Großstadt Architektur (Stuttgart: Julius Hoffmann, 1927); recently translated into English as "metropolisarchitecture," in Metropolisarchitecture and Selected Essays, trans. Richard Anderson (New York: GSAPP Books, 2012).

6. In the context of the German discourse alone, works by figures such as Reinhard Baumeister, Herman Josef Stübben, Theodor Fritsch, and Martin Wagner show the difference in mentality.

7. Marshall Berman in All That Is Solid Melts into Air: The Experience of Modernity (New York: Simon and Schuster, 1982) describes the shift from the nineteenth-century commitment to wrestle with the tensions within modernity to the twentieth-century polarization between the embrace and rejection of the modern condition. He portrays this as a transition from "Both/And" to "Either/Or" (24). I explain the latter ("Either/Or") as a categorical discourse within modernity. Scheffler's writings on the city and Messel's buildings for the metropolis break open this categorical discourse.

8. Berman, All that Is Solid Melts into Air, 36.

9. Writing without much inhibition came naturally to Scheffler, who as an autodidact with no university education was not burdened by academic alliances. The unique cultural climate of Berlin quickly noticed Scheffler's tone in his first articles in the late 1890s and brought him in contact with people such as Henry van de Velde and Peter Behrens. His early writings appeared in the magazines Atelier and Dekorative Kunst in 1897. Later, he began publishing articles in the better-known Die Zukunft and broadened his contributions to more popular papers, such as the Frankfurter Zeitung, the Münchner Nachrichten, 
the Neue Rundschau, as well as the Weltbühne, which explains his influence not only on the art scene but also on the general public. Despite the diversity, amount, and extensive circulation of Scheffler's writings, surprisingly little scholarship exists on his work. For a cultural placement of Scheffler, see David Frisby, Cityscapes of Modernity: Critical Explorations (Malden, MA: Polity Press, 2001). For his relationship to the Berlin Secession and the later Werkbund, see Peter Paret, The Berlin Secession: Modernism and Its Enemies in Imperial Germany (Cambridge, MA: Harvard University Press, 1980); and Mark Jarzombek, "The Kunstgewerbe, the Werkbund, and the Aesthetics of Culture in the Wilhelmine Period," Journal of the Society of Architectural Historians 53 (March 1994): 7-19. For earlier interpretations of Scheffler's influence on modernity, see Julius Posener, Berlin auf dem Wege zu einer neuen Architektur: Das Zeitalter Wilhelms II, Studien zur Kunst des Neunzehnten Jahrhunderts (Munich: Prestel, 1979); Francesco Dal Co, Figures of Architecture and Thought: German Architecture Culture, 1880-1920 (New York: Rizzoli, 1990); and Massimo Cacciari's compendium of essays from the 1970s, Architecture and Nihilism: On the Philosophy of Modern Architecture (New Haven: Yale University Press, 1993).

10. In his autobiographies Der Junge Tobias (The young Tobias, 1927) and Die Fetten und die Mageren Jahre (The rich and meager years, 1946), Scheffler speaks of the relationship between his thinking and the urban modernization during which he grew up. The changes that penetrated all aspects of life were seen most drastically in the emergence of modern urbanity-the expansion of the modern city and the geographic and cultural shifts that this change brought. He reports, for example, that the village of his childhood "was still entirely rural; today it is a suburb of a metropolis" (Der Junge Tobias, 9). When Scheffler arrived in Berlin (1888), the city had transformed into an industrial landscape with the construction of 500 new factories in the 1880s alone. Karl Scheffler, Der junge Tobias: Eine Jugend und ihre Umwelt (Leipzig: Insel-Verlag, 1927); and Karl Scheffler, Die fetten und die mageren Jahre: Ein Arbeits- und Lebensbericht (Leipzig and Munich: Paul List Verlag, 1946).

11. With his writings, Scheffler not only supported German impressionism but prepared the ground for later avant-gardes (especially expressionism). However, he was unable to recognize the advances of this emerging generation, which, he argued, "had little to offer." Scheffler, Die fetten und die mageren Jahre, 69. For further references by Scheffler on art, see "Kunstausstellungen," Kunst und Künstler 6 (1907-1908): 256, 370; "Kunstausstellungen," Kunst und Künstler 9 (1910-1911): 308, 364; and "Kunstausstellungen," Kunst und Künstler 12 (1913-1914): 119; as well as "Berliner Sezession," in Kunst und Künstler 8 (1910-1911): 308, 364.

12. By the end of the nineteenth century, artists such as Max Liebermann, Franz Skarbina, Hans Baluschek, and Lesser Ury were experimenting with new perceptual qualities that were also on the agenda for aestheticians such as Robert Vischer, Conrad Fiedler, Heinrich Wölfflin, Adolf Göller, Adolf von Hildebrand, August Schmarsow, Ernst Mach, and Theodor Lipps.

13. Part 2 of Die Schönheit der Großen Stadt, translated by Zeynep Çelik Alexander, is included in this issue of Grey Room.

14. For further information on Endell's use of impressionism, see my "Visual Discoveries of an Urban Wanderer: August Endell's Perception of a Beautiful Metropolis," Arq: Architectural Research Quarterly 11, no. 1 (March 2007): 71-80; and Lothar Müller, "The Beauty of the Metropolis: Towards an Aesthetic Urbanism in Turn-of-the-Century Berlin," in Berlin: Culture and Metropolis, ed. Charles W. Haxthausen and Heidrun Suhr (Minneapolis: University of Minnesota 
Press), 37-57.

15. Manfredo Tafuri and Francesco Dal Co, Modern Architecture (New York: H.N. Abrams, 1979), 11, 14; Dal Co, Figures of Architecture and Thought, 53, 55; Cacciari, Architecture and Nihilism, 88; and Posener, Berlin auf dem Wege zu einer neuen Architektur, 252.

16. Scheffler, Moderne Baukunst, 1.

17. Scheffler, Moderne Baukunst, 1.

18. Scheffler, Berlin-Ein Stadtschicksal, 116.

19. Scheffler, Berlin-Ein Stadtschicksal, 14-15.

20. Walter Benjamin, "The Work of Art in the Age of Its Technological Reproducibility [Second Version]" (1936), trans. Edmund Jephcott and Harry Zohn, in Selected Writings, vol. 3, 1935-1938, ed. Howard Eiland and Michael W. Jennings (Cambridge, MA: Belknap Press, 1996), 127. For the original German, see Walter Benjamin, Das Kunstwerk im Zeitalter seiner technischen Reproduzierbarkeit; Drei Studien zur Kunstsoziologie (Frankfurt: Suhrkamp Verlag, 1963). For further reading on Benjamin's use of the terms "Spielraum" and "Spiel," see Miriam Bratu Hansen, "Room-for-Play: Benjamin’s Gamble with Cinema,” October 109 (Summer 2004): 3-45.

21. Scheffler, Berlin-Ein Stadtschicksal, 212.

22. These characteristics are developed in Scheffler's Berlin-Ein Stadtschicksal, in which Scheffler associates Berlin with different types of cities except the traditional town: Kolonialstadt, Kaiserstadt, Reichshauptstadt, Großstadt, Geschäftsstadt, Arbeitsstadt, Vergnügungsstadt (211).

23. Scheffler, Berlin-Ein Stadtschicksal, 9.

24. Scheffler, Berlin-Ein Stadtschicksal, 15.

25. Karl Baedeker (Firm), Berlin and Its Environs: Handbook for Travelers (Leipzig: K. Baedeker, 1908), v.

26. For further reading on the discourse around the German department store, see Posener, Berlin auf dem Wege zu einer neuen Architektur; Peter Stürzebecher, Das Berliner Warenhaus: Bautypus, Element der Stadtorganisation, Raumsphäre der Warenwelt (Berlin: Archibook-Verlag, 1979); and Tilmann Buddensieg, ed., Berlin, 1900-1933: Architecture and Design, Architektur und Design (New York: Cooper-Hewitt Museum, 1987). For more recent accounts of Messel's Wertheim store, see Helen Shiner, "Embodying the Spirit of the Metropolis, the Warenhaus Wertheim, Berlin, 1896-1904," in Modernism and the Spirit of the City, ed. Iain Boyd Whyte (London: Routledge, 2003), 97-118; and Kathleen James, "From Messel to Mendelsohn: German Department Store Architecture in Defence of Urban and Economic Change," in Cathedrals of Consumption: The European Department Store, 1850-1939, ed. Geoffrey Crossick and Serge Jaumain (Aldershot, UK: Ashgate, 1999), 252-278. For contemporary accounts of the department store, see Paul Göhre, Das Warenhaus (Frankfurt: Rütten und Loening, 1907); Leo Colze, Berliner Warenhäuser (1908; Berlin: Fannei und Walz Verlag, 1989); Alfred Wiener, "Das Warenhaus," in Jahrbuch des deutschen Werkbundes (Jena: Eugen Diedrichs, 1913), 43-54; and Adolf Behne, Der moderne Zweckbau (Vienna/Berlin: Drei Masken Verlag, 1926), translated as The Modern Functional Building (Santa Monica: Getty Research Center for the History of Art and the Humanities, 1996).

27. For further information on the history of the department store, see Geoffrey Crossick and Serge Jaumain, eds., Cathedrals of Consumption; Bernard Marrey, Les Grands Magasins des origines à 1939 (Paris: Picard, 1979); Nikolaus Pevsner, "Shops, Stores and Department Stores," in A History of Building Types (Princeton, NJ: Princeton University Press, 1976), 267-270; and Joseph Siry, Carson Pirie Scott: Louis Sullivan and the Chicago Department Store (Chicago: 
University of Chicago Press, 1988).

28. Frederic J. Schwartz, The Werkbund: Design Theory and Mass Culture before the First World War (New Haven: Yale University Press, 1996), 46.

29. Emil Claar, "Die Welt im Kleinen," in Deutsche Großstadtlyrik vom Naturalismus bis zur Gegenwart (Stuttgart: Reclam, 1975), 67.

30. The fairgrounds consisted of 1.1 million square meters and entailed the construction of the city train station Treptower Park, the erection of Oberbaumbrücke, and improvements of numerous streets in the vicinity.

31. "Berlin's Splendid Fair-All the World Is Expected, and Financial Success Assured,” New York Times, 10 May 1896.

32. Walter Benjamin, "Paris-the Capital of the Nineteenth Century" (1935), trans. Quintin Hoare, in Charles Baudelaire: A Lyric Poet in the Era of High Capitalism (London: New Left Books, 1973), 165.

33. The term Traumbilder was used as a title for the combined publication of multiple visions for the Berlin exhibition: "Traumbilder von der Berliner Weltausstellung," in Bierzeitung des Berliner Architektenvereins (Berlin, 1896).

34. Sigfried Giedion, "Part III: The Evolution of New Potentialities," in Space, Time and Architecture (1941; Cambridge, MA: Harvard University Press, 1962).

35. Georg Simmel, "The Berlin Trade Exhibition," in Simmel on Culture: Selected Writings, ed. and trans. David Frisby and Mike Featherstone (London: Sage Publications, 1997), 257.

36. Simmel, "The Berlin Trade Exhibition," 255-256.

37. A great amount has been written on the topic of the World Expositions and the way these cultural vehicles often presented imagery that stimulated urban and architectural discouse. For examples of this literature, see John Allwood, The Great Exhibitions (London: Studio Vista, 1977); Paul Greenhalgh, Ephemeral Vista: The Expositions Universelles, Great Exhibitions and the World's Fairs (Manchester: Manchester University Press, 1988); Paul Greenhalgh, Fair World: A History of World's Fairs and Expositions from London to Shanghai 1851-2010 (London: Papadakis, 2011); Deborah Silverman, "The Paris Exhibition of 1889: Architecture and the Crisis of Individualism," Oppositions 8 (Spring 1977): 70-91; and Robert Rydell, All the World's a Fair (Chicago: University of Chicago Press, 1984). See also Mabel O. Wilson, Negro Building: Black Americans in the World of Fairs and Museums (Berkeley and Los Angeles: University of California Press, 2012).

38. Walter Benjamin, "Paris, Capital of the Nineteenth Century," in Reflections, trans. Edmund Jephcott (New York: Schocken Books, 1978), 156. Additionally, see Benjamin, The Arcades Project, trans. Howard Eiland and Kevin McLaughlin (Cambridge, MA: Belknap Press, 1999), 10, 15, 21, 37, 40-48, 60-61. Benjamin made frequent use of Giedion's Bauen in Frankreich, which made a great impression on him. See Detlef Mertins, "The Enticing and Threatening Face of Prehistory: Walter Benjamin and the Utopia of Glass," Assemblage 29 (April 1996): 7.

39. I am here building on a trajectory that leads from Benjamin via Giedion to Mertins. See Detlef Mertins, "Walter Benjamin and the Tectonic Unconscious: Using Architecture as an Optical Instrument," ANY 14 (1996): 28-35.

40. For a more detailed history of the Wertheim Emporium, see Robert Habel, Alfred Messels Wertheimbauten in Berlin (Berlin: Gebr. Mann Verlag, 2009); and Alfred Messel: Visionär der Großstadt, ed. Elke Blauert, Robert Habel, Hans-Dieter Nägelke, and Christiane Schmidt (Berlin: Staatliche Museen zu Berlin; Munich: Edition Minerva Hermann Farnung, 2009).

41. Peter Behrens, "Alfred Messel: Ein Nachruf," Frankfurter Zeitung, 6 April 
1909 (morning ed.), 225; and Iain Boyd Whyte, Bruno Taut and the Architecture of Activism (Cambridge, UK: Cambridge University Press, 1982), 17.

42. Walter Curt Behrendt, Alfred Messel: Mit einer einleitenden Betrachtung von Karl Scheffler (Berlin: Bruno Cassirer Verlag, 1911), 28-29.

43. For further reading on the U.S. influence on Germany, see Frank Trommler, "The Rise and Fall of Americanism in Germany," in America and the Germans: An Assessment of a Three-Hundred-Year History, ed. Frank Trommler and Joseph McVeigh (Philadelphia: University of Pennsylvania Press, 1985); Amerikanisierung: Traum und Alptraum im Deutschland des 20. Jahrhunderts, ed. Alf Lüdtke, Inge Marßolek, and Adelheid von Saldern (Stuttgart: Franz Steiner Verlag, 1996); and Alexander Schmidt, Reise in die Moderne (Berlin: Akademie Verlag, 1997). For further reading on the German perception of the United States, see Ulrich Ott, Amerika ist Anders: Studien zum Amerika-Bild in deutschen Reiseberichten des 20. Jahrhunderts (Frankfurt: Lang, 1991). For early articulations of the relationship between Berlin and cities in the United States (particularly Chicago), see William Thomas Stead, The Americanization of the World: The Trend of the Twentieth Century (London: Horace Markley Publishing, 1901); Walther Rathenau, Die schönste Stadt der Welt (1899; Berlin: Philo, 2001); and Mark Twain, "The German Chicago," in The Complete Essays of Mark Twain (Garden City, NY: Doubleday, 1963). For further reading on the urban and architectural transatlantic exchange between Berlin and Chicago, see my essay "No Failure Too Great," in Chicagoisms: The City as Catalyst for Architectural Speculation, ed. Alexander Eisenschmidt with Jonathan Mekinda (Zürich: Scheidegger \& Spiess/Park Books, 2013), 150-166.

44. Hand Vollman, "Berlins neuestes Warenhaus und sein Architekt," Norddeutsche Allgemeine Zeitung, 15 November 1897, 376.

45. Rathenau, Die schönste Stadt der Welt, 23. Originally published anonymously as "Die schönste Stadt der Welt," Die Zukunft 26 (1899): 36-48. This essay found wide distribution through Rathenau's collection of essays, Impressionen (Leipzig: S. Hirzel, 1902).

46. Scheffler, Berlin-Ein Stadtschicksal, 161.

47. Scheffler, Berlin-Ein Stadtschicksal, 197.

48. Scheffler, Moderne Baukunst, 48.

49. Scheffler, Moderne Baukunst, 48.

50. Göhre, Das Warenhaus, 12.

51. Gebäudekunde: Baukunde des Architekten, vol. 2, no. 5 (Berlin: Verlag Deutsche Bauzeitung, 1902), 157.

52. Posener, Berlin auf dem Wege zu einer neuen Architektur, 453-458.

53. In his early essay "Soziologische Aesthetik" (Sociological aesthetic), Die Zukunft, 1896, 204-216, Simmel speaks of the "Reiz des Fragments" (stimulus of the fragment). For a closer investigation of the notion of "fragmentation," see David Frisby, Fragments of Modernity: Theories of Modernity in the Work of Simmel, Kracauer, and Benjamin (Cambridge, MA: MIT Press, 1986).

54. This cast of characters is outlined in the work of Benjamin and Kracauer as they investigated spaces within the modern metropolis-realms they called "worlds in themselves." See Kracauer, "Die Hotelhalle," in Das Ornament der Masse: Essays (Frankfurt: Suhrkamp, 1977).

55. Baedeker, Berlin and Its Environs, 12.

56. Berlin für Kenner: Ein Bärenführer bei Tag und Nacht durch die deutsche Reichshauptstadt (Berlin: Boll und Pickardt Verlag, 1912), quoted in Jürgen Schutte and Peter Sprengel, eds., Die Berliner Moderne 1885-1914 (Stuttgart: Reclam, 1997), 97-98.

57. Karl Scheffler, "Das Geschäftshaus: Der Architekt Alfred Messel“ (1908), 
in Der Architekt—und andere Essays über Baukunst, Kultur und Stil (Berlin: Birkhäuser, 1993), 25.

58. Wolf Wertheim (the youngest of the Wertheim brothers), who was responsible for the building, had to pay 100 gold marks several times as a fine to the police because of the overcrowding of certain locations in the department store. Landesarchiv Berlin, B Rep. 202, no. 4110.

59. Berlin für Kenner, quoted in Die Berliner Moderne 1885-1914, 98.

60. Scheffler used the term in 1910 to describe the Wertheim store in BerlinEin Stadtschicksal and he elaborated on the term in Die Architektur der Großstadt.

61. Scheffler, Die Architektur der Großstadt (1913; Berlin: Gebr. Mann, 1998), 118-119. See also Scheffler's introductory text in Behrendt, 15.

62. Scheffler, Die Architektur der Großstadt (1998), 11.

63. Scheffler, Die Architektur der Großstadt (1998), 39. "Messel, despite his exemplary modern thinking, was still too much an academic and child of tradition, which made it impossible for him to entirely solve the great missions of our time. [After all] the most valuable characteristic [of modern building] is the impersonal and typical."

64. The Wertheim store expansion took place in three stages: 1896-1897, 1899-1900, and 1904-1906.

65. Scheffler, Die Architektur der Großstadt (1998), 33, 36.

66. Behrendt completed his doctorate in architecture at the Technical University of Dresden in 1911.

67. Scheffler, Die Architektur der Großstadt (1998), 17-18.

68. This reading of architecture's at times productive engagements with some of the more hostile conditions of the commercial city runs counter to the predominant understanding of this early material cultivated by Tafuri, Dal Co, and Cacciari. More recently, however, the urbanism of the "superblock" has been productively revisited by Sarah Whiting, who shows that even the postwar urban developments in the United States (particularly at Chicago's Near South Side in the 1940s) produced innovations and a "new form of public intersubjectivity." See Sarah Whiting, "Super!” Log 16 (Spring/Summer 2009): 19-26; and Sarah Whiting, "Bas-Relief Urbanism: Chicago's Figured Field," in Mies in America, ed. Phyllis Lambert (New York: Harry N. Abrams, Centre Canadien d'Architecture, Whitney Museum of American Art, and Museum of Modern Art, 2001), 642-691.

69. Bruno Taut, Competition Entry for the Extension of the Wertheim Warenhaus, Berlin, 1910. For further information, see Posener, Berlin auf dem Wege zu einer neuen Architektur, 478.

70. Peter Behrens, "Einfluss von Zeit- und Raumausnutzung auf moderne Formentwicklung," in Jahrbuch des Deutschen Werkbundes: Der Verkehr (Jena: Eugen Dietrichs, 1914), 7-10.

71. Erich Mendelsohn, Das Gesamtschaffen des Architekten (Berlin: Rudolf Mosse Buchverlag, 1930), 28.

72. Scheffler, Die Architektur der Großstadt (1998), 30-40. 